\title{
CORRELATION BETWEEN ANXIETY IN MOTHERS AND CHILDREN WITH SENSORY IMPAIRMENTS BEFORE DENTAL TREATMENT
}

\author{
MARGARETHA SOVARIA ${ }^{1}$, EKA S SHOFIYAH ${ }^{1}$, MOCHAMAD F RIZAL ${ }^{2 *}$, SARWORINI B BUDIARDJO ${ }^{2}$ \\ ${ }^{1}$ Department of Pediatric Dentistry Residency Program, Faculty of Dentistry, Universitas Indonesia, Jakarta, Indonesia. ${ }^{2}$ Department of \\ Pediatric Dentistry, Faculty of Dentistry, Universitas Indonesia, Jakarta, Indonesia. Email: Levipedo@gmail.com
}

Received: 16 September 2017, Revised and Accepted: 3 October 2017

\section{ABSTRACT}

Objective: Mothers have very important roles in their children's development. Their instinctive love develops strong emotional connections with their children, especially when their children have sensory impairments (SI). Feelings experienced by mothers, such as anxiety toward dental treatment, can affect their children's emotions. Salivary alpha amylase (sAA) has been proposed as a biomarker of stress due to its sensitivity to changes in the body, such as dental anxiety. This study aimed to analyze the relationship between sAA levels in mothers and children with SI before dental treatment.

Methods: Measurement of sAA from sixty pairs of children with SI and their mothers was taken together in the waiting room before the children's dental treatment. Spearman's analysis was used to find the correlation between their sAA levels.

Results: In this study, sAA levels in mothers accompanying their children with SI correlated significantly with their children's sAA levels (r=0.533; $\mathrm{p}<0.002)$.

Conclusions: The correlation between dental anxiety in mothers and children with SI before dental treatment was found to be significant.

Practical Implications: Anxiety toward dental care is a phenomenon that frequently arises in children. Mothers, the main influencers of their children's development, are thought to be one cause of high anxiety in children. Children with special needs are at a higher risk for developing dental problems. Therefore, an understanding of these children's levels of anxiety can be used by pediatric dentists to improve dental care.

Keywords: Salivary alpha amylase, Anxiety, Children, Sensory impairment, Before dental treatment.

(c) 2017 The Authors. Published by Innovare Academic Sciences Pvt Ltd. This is an open access article under the CC BY license (http://creativecommons. org/licenses/by/4. 0/) DOI: http://dx.doi.org/10.22159/ijap.2017.v9s2.39

\section{INTRODUCTION}

Dental anxiety is a common phenomenon which affects the process of delivering proper dental care to society in almost all age ranges [1,2]. The causes of this problem vary from lack of knowledge to environmental perception. The pediatric treatment triangle theory by Wright explains that, in treating children, communication is a 1:2 relationship between the dentist and the children and their parents, whereas in treating adults, it is only a 1:1 communication [3]. Successful communication regarding dental treatment can overcome feelings of anxiety. In children with sensory impairment (SI), this communication challenge expands because their special condition requires a different approach [4]. These children tend to have a stronger dependency on their caregivers, in most cases their mothers, and their physical and emotional relationships are more intense compared to children without SI [5].

A mother's care for her children is considered a natural instinct which leads to a strong emotional relationship between them [6]. This strong connection, however, also works for negative feelings like anxiety. Dentists need to fully understand anxiety and its effects on children's behavior as a foundation for building trust both in children and parents [1].

Salivary alpha amylase (sAA) is one of the major proteins in saliva and accounts for $40-50 \%$ of the protein produced by the salivary glands. Activation of the autonomic nervous system has a strong influence over the salivary glands and controls the secretion of sAA [7]. It is considered a reliable biomarker of stress and is preferred as a noninvasive procedure among several other methods because it does not cause distress to the subject [2,7-9]. The activity of sAA is reported to increase during distress and decrease during comfort [10].
Research about anxiety in mothers and their children during dental treatments and the effects on their dental health has been conducted in many countries. However, not much research focusing on children with SI and their dental health has been done even though these children are at higher risk for dental problems.

The objective of this research is to analyze the relationship between sAA levels in mothers and their children with SI before dental treatment.

\section{METHODS}

Sixty pairs of children with SI age 5 and above who registered as students in a school for the sensory impaired in Jakarta, Indonesia, and their mothers participated in this study. The exclusion criteria were mothers and children with asthma, diabetes, kidney failure, congenital heart disease, salivary gland disorder, and pancreatitis. Mothers and children were also excluded if they were on beta blockers, antidepressants, parasympathetic medications, or long-term steroids. Further, children who had experience with dental treatment did not cooperate or had tests or sporting activities at school on the day of sampling were excluded from the study.

Measurements of sAA were taken from both mothers and children in the waiting room before dental examination using a handheld sAA monitor according to the manufacturer's instructions (Nipro, Osaka, Japan). A strip to collect saliva was positioned under the tongue for 30 seconds and then directly placed in the handheld device to be analyzed. Levels of SAA were revealed in the monitor within 30 seconds [10]. Spearman's analysis was used to find the correlation between the sAA levels of mothers and their children before the children's dental treatment. 


\section{RESULTS}

Table 1 summarizes that the average sAA level was higher in mothers than in their children before dental treatment, and this difference was found to be statistically significant. A positive correlation was also found to be statistically significant between sAA levels in mothers and their children with SI before dental treatment (Table 2).

\section{DISCUSSION}

Association between maternal dental anxiety and children's dental anxiety has been found in several studies, and even further, mothers' fears have been found to affect their children's dental caries experience $[10,11]$. In this research, focusing on children with SI, we found that their anxiety was significantly correlated with their mother's anxiety even before they experienced their first dental treatments. Children with SI were studied in our research because this specific group is at a higher risk of dental problems due to their dependency [12].

In this research, mothers and children were both measured while they sat together in a room, waiting for the children's first dental treatment. Opinions regarding the effect of parental presence in the dental operatory during a child's dental treatment vary among clinicians, educators, and researchers. The American Academy of Pediatric Dentistry includes parental presence or absence as a method to help establish effective dentist-child communication during dental treatment. A parent's desire to be present during her child's treatment does not necessarily mean she distrusts the dentist. Instead, it might mean that she is uncomfortable if she cannot verify her child's safety visually [13]. Research shows, and similar results were found in this study, that parental presence is beneficial in reducing children's psychological trauma and results in less distress during and after medical treatments $[14,15]$.

Sensory impaired individuals are known to have higher anxiety, especially toward physical threats [16]. The significant correlation in sAA levels between mothers and children with SI found in this study is possibly the result of their strong emotional bonding. As mentioned by Ardito et al. (2004), mothers of children with disabilities show a high frequency of maternal directive and overprotective behaviors when interacting with their children. This manner can influence both the development and personality of their children [17].

According to the theory of attachment, continuous interactions with caregivers, which with special needs children is often their mothers, form a structure of knowledge deriving from repeated interactions between the child and the figure of attachment known as an internal

Table 1: Average $( \pm S D)$ sAA level of mothers and their children with SI before dental treatment

\begin{tabular}{lc}
\hline & \multicolumn{1}{c}{ Average (minimum-maximum) } \\
\hline Mothers & $43^{*}(2-163)$ \\
Children with SI & $29.5^{*}(2-113)$ \\
\hline $\begin{array}{l}\left.{ }^{*} \mathrm{p}<0.05 \text { (Wilcoxon signed-rank test, } \mathrm{p}=0.001\right), \mathrm{sAA} \text { : Salivary alpha amylase. SI: } \\
\text { Sensory impairment }\end{array}$ \\
$\begin{array}{ll}\text { Table 2: Correlation coefficients between sAA levels of mothers } \\
\text { and their children with sensory impairment before dental } \\
\text { treatment }\end{array}$ \\
\begin{tabular}{ll}
\multicolumn{2}{c}{ sAA children with SI } \\
\hline sAA mothers & $\mathrm{r}=0.533$ \\
& $\mathrm{p}=0.002^{*}$ \\
$\mathrm{n}=60$
\end{tabular} \\
\hline
\end{tabular}

${ }^{*} \mathrm{p}<0.05$ (Spearman's correlation test), sAA: Salivary alpha amylase. SI: Sensory impairment working model. It begins to develop from the $1^{\text {st }}$ year of life and tends to remain stable into adulthood [18].

From a pediatric dentistry point of view, the results seen in our study are highly beneficial and can be used in clinical practice. Relating our results to the pediatric treatment triangle theory by Wright, effective communication with both the caregivers, and the children as patients are key to the achievement of successful dental treatment, while failure in managing one of them might otherwise interfere with care [3].

Our findings also showed that knowing the level of a mother's anxiety can be used to predict how her child with SI will react to dental treatment

This information is valuable because dentists can better decide which behavior management technique to apply in advance without the need for a trial-and-error method in daily practice. In reverse, as a preventative approach, early dental education can target anxious mothers detected by their sAA levels, so they can transmit positive feelings toward dental treatment to their children with SI.

\section{CONCLUSION}

Our study showed a significant correlation between dental anxiety in mothers and their children with SI before dental treatment. Basic knowledge of patients' levels of anxiety in this specific group is needed by pediatric dentists to deliver adequate dental care. Children with special needs are at a higher risk for dental problems. Therefore, more research should be done in other special need patients to study the effect that different disabilities may have on children's behavior. In this way, dentists can understand how to more effectively deliver care to their most vulnerable patients.

\section{ACKNOWLEDGMENT}

This research was carried out under grants from Hibah Publikasi Internasional Terindeks Untuk Tugas Akhir Mahasiswa (PITTA) 2016, Directorate of Research and Community Engagement, Universitas Indonesia and University of Indonesia Oral Sc. Research Center (UIOSRC).

The publication of this manuscript is supported by Universitas Indonesia

\section{REFERENCES}

1. Assuncão CM, Losso EM, Andreatini R, de Menezes JV. The relationship between dental anxiety in children, adolescents and their parents at dental environment. J Indian Soc Pedod Prev Dent 2013;31:175-9.

2. Sadi H, Finkelman M, Rosenberg M. Salivary cortisol, salivary alpha amylase, and the dental anxiety scale. Anesth Prog 2013;60:46-53.

3. Wright GZ, Kupietzky A. Behaviour Management in Dentistry for Children. $2^{\text {nd }}$ ed. Iowa: John Wiley \& Sons, Inc.; 2014. p. 248

4. Mangunsong F. Psikologi dan Pendidikan Anak Berkebutuhan Khusus. Jilid Satu. Depok: LPSP3 UI; 2009.

5. Andayani BK. Peran Ayah Menuju Coparenting. Sidoarjo: Laros; 2007.

6. Gunarsa SD. Psikologi Praktis: Anak, Remaja, dan Keluarga. Jakarta: PT BPK Gunung Mulia; 2004

7. Brown NJ, Kimble RM, Rodger S, Ware RS, McWhinney BC, Ungerer JP, et al. Biological markers of stress in pediatric acute burn injury. Burns 2014;40:887-95.

8. McKay KA, Buen JE, Bohan KJ, Maye JP. Determining the relationship of acute stress, anxiety, and salivary alpha-amylase level with performance of student nurse anesthetists during human-based anesthesia simulator training. AANA J 2010;78:301-9.

9. Noorani H, Joshi HV, Shivaprakash P. Salivary alpha amylase as a noninvasive biomarker for dental fear and its correlation with behavior of children during dental treatment. Int J Clin Pediatr Dent 2014; $7: 19-23$

10. Karibe H, Aoyagi-Naka K, Koda A. Maternal anxiety and child fear during dental procedures: A preliminary study. J Dent Child (Chic) 2014;81:72-7. 
11. Goettems ML, Ardenghi TM, Romano AR, Demarco FF, Torriani DD. Influence of maternal dental anxiety on the child's dental caries experience. Caries Res 2012;46:3-8.

12. Mahoney EK, Kumar N, Porter SR. Effect of visual impairment upon oral health care: A review. Br Dent J 2008;204:63-7.

13. American Academy of Pediatric Dentistry. Guideline on behavior guidance for the pediatric dental patient: Reference manual. Pediatr Dent 2015;37:180-93.

14. Kim JS, Boynton JR, Inglehart MR. Parents' presence in the operatory during their child's dental visit: A person-environmental fit analysis of parents' responses. Pediatr Dent 2012;34:407-13.
15. Pani SC, AlAnazi GS, AlBaragash A, AlMosaihel M. Objective assessment of the influence of the parental presence on the fear and behavior of anxious children during their first restorative dental visit. J Int Soc Prev Community Dent 2016;6:S148-52.

16. Ollendick TH, Matson JL, Helsel WJ. Fears in visually-impaired and normally-sighted youths. Behav Res Ther 1985;23:375-8.

17. Ardito RB, Adenzato M, Dell'Osbel G, Izard E, Veglia F. Attachment representations in adults with congenital blindness: Association with maternal interactive behaviors during childhood. Psychol Rep 2004;95:263-74

18. Bowlby J. Attachment and Loss. New York: Basic; 1982. p. 1-325. 